Article

\title{
Sculptures and Accessories: Domestic Piety in the Norwegian Parish around 1300
}

\author{
Ragnhild M. Bø \\ Department of Archaeology, Conservation and History, University of Oslo, P.O. Box 1008 Blindern, 0315 Oslo, \\ Norway; r.m.bo@iakh.uio.no
}

Received: 29 October 2019; Accepted: 14 November 2019; Published: 19 November 2019

\begin{abstract}
Eagerly venerated and able to perform miracles, medieval relics and religious artefacts in the Latin West would occasionally also be subject to sensorial and tactile devotional practices. Evidenced by various reports, artefacts were grasped and stroked, kissed and tasted, carried and pulled. For medieval Norway, however, there is very little documentary and/or physical evidence of such sensorial engagements with religious artefacts. Nevertheless, two church inventories for the parish churches in Hålandsdalen (1306) and Ylmheim (1321/1323) offer a small glimpse of what may have been a semi-domestic devotional practice related to sculpture, namely the embellishing of wooden sculptures in parish churches with silver bracelets and silver brooches. According to wills from England and the continent, jewellery was a common material gift donated to parishes by women. Such a practice is likely to have been taking place in Norway, too, yet the lack of coherent source material complicate the matter. Nonetheless, using a few preserved objects and archaeological finds as well as medieval sermons, homiletic texts and events recorded in Old Norse sagas, this article teases out more of the significances of the silver items mentioned in the two inventories by exploring the interfaces between devotional acts, decorative needs, and possibly gendered experiences, as well as object itineraries between the domestic and the religious space.
\end{abstract}

Keywords: holy crosses; wooden crucifixes; pendants; silver arm rings; parish churches; gift-giving; popular piety; devotional practices

\section{Introduction}

In the Middle Ages, people's engagement with sculptures took many forms. Sculptures, as well as manuscript pages, relics and reliquaries, could be grasped, stroked, kissed and tasted; at times they were felt as becoming living flesh under the hands of the devout (Freedberg 1989; Bynum 2011; Rosler et al. 2013) and they could be dressed and undressed (Trexler 1991; Genovese 2011). Sculptures, and in particular crucifixes, could also act themselves (Tripps 2000; Kopania 2010). Appearing to be animated, they took on a "practical mediatory role (... ) in the social process" (Gell 1998, p. 6) and participated in a phenomenological animation, that is the animation which takes place in the beholder's response to and encounter with them (Lohfert Jørgensen 2017, p. 266; also see Pongratz-Leisten and Sonik 2015). Regardless of perceived animations, however, sculptures were at times recipients of precious accessories, often as the result of a pious bequest (Marks 2004; French 2008). Although source material for people's engagements with sculptures in medieval Norway is very scant, such bequests are possibly what are referenced in two unique documents from the fourteenth-century, namely the inventories from the parish churches of Hålandsdalen (1306) and Ylmheim (1321, additions from 1323).

Hålandsdalen (today Holdhus) and Ylmheim (today Ølmheim) were both under the jurisdiction of Bjørgvin bishopric and situated at the western coast of Norway, yet more than 200 kilometres apart. Unfortunately, none of the churches for which the inventories were made are preserved; the present churches date from 1726 and 1863 respectively (Hoff 1997). However, as words have outlived the 
monuments, we can appreciate matchless windows into the contemporary medieval parish church interior. Commencing with the liturgical textiles, the inventories list chasubles, alba, antependia (frontals), dossals and altar cloths-in fact, the entire choir of Hålandsdalen was filled with textiles, ræflum and tioldum. ${ }^{1}$ Church bells, liturgical bells, censers, chalices and corpora follow suit as well as candlesticks, crosses, bearskins and liturgical manuscripts such as missals, manuals, psalters and vitae. The inventories largely converge, but there are more items of each category in Ylmheim and a slight variation in the number of paintings and sculptures. However, the object from Hålandsdalen described as "one large cross with Mary and John with six silver rings, three on each arm, and one silver brooch" (DN 21,7) is matched in Ylmheim by "a cross dressed in pxll with two silver rings around the waist and six around the arms" (DN 15, 8). ${ }^{2}$

The early fourteenth-century compilers recorded virtually all the churches' possessions through brief descriptions, yet also included more qualitative judgements such as the weight of the censer (ærtog fa[t]t a vii. aura ${ }^{3}$ ), the different size and age of the manuscripts (small, old) and the different fabrics (pellz, camelot, fustane ${ }^{4}$ ) and colours (red and green) of the liturgical textiles. One of the antependia is even characterized as useless. Moreover, both inventories disclose a detail—and possibly a related devotional act—namely the embellishing of crucifixes and sculptures with silver bracelets and silver brooches. Although these descriptions are brief, it is intriguing that the only fourteenth-century church inventories which have been conserved for posterity both mention crucifixes with silver arm rings (silfr spongum). Furthermore, these are the only instances of such wording in the entire corpus of preserved medieval documents from Norway, and indeed Scandinavia.

The last decade has seen an increasing interest in medieval inventories and other documents listings things. They are valuable sources for the reconstruction of collections now lost or dispersed (Keane 2016) and they can reveal a number of cultural practises involving material culture such as debt-collection (Smail 2016), the supply of artistic materials (Kirby et al. 2010), gift-giving (Algazi et al. 2003) and pious bequests (Smith et al. 2001; French 2008). The brevity of the inventories from Hålandsdalen and Ylmheim, however, complicates the matter; apart from noting the presence of the silver items, they are silent about their appearance and function. Were the arm rings an integral part of the sculpture from the time of its execution, or were they later additions? Were they placed as embellishments, votive gifts, or heirlooms? Or, were they placed on the crucifix in order to create a portable amulet which could be relocated from the religious to secular or domestic sphere when needed?

This article aims to reach a better understanding of the bracelets and the brooch by analysing preserved crucifixes and related material culture as well as examining how the possession of religious object in households and the care for objects in local churches are portrayed in saga literature, normative texts and wills. Comparing the finds from early fourteen-century Norway with devotion to the cross and crucifixes, patterns of pious bequests and the laity's engagement in parish churches in England and on the continent allows for further assumptions about the silver items. The comparison appears particularly appropriate if the silver items are considered to be acts of domestic devotion; not, however, in the form of devotions carried out in a private home (Brundin et al. 2018; Corry et al. 2018), but as a way the laity would integrate themselves into parish communities through domestic and secular objects.

1 Rxflum/refil is a rectangular, horizontally cut textile often with iconographical motifs; tioldum/tjeld are textiles hang on the wall in larger pieces.

2 "Jtem æin kross stor cum mari et Johanne med sex silfr spongum priar vm huarn arm ok [æ]in silfr sylgia" and "Jtem æinn kross klædr med ok pæll tuæimr silfr spongum vm mitt ok vi vm armanna."

3 Eight öre but one örtug. Öre $=1 / 8$ mark and örtug $=1 / 24$ mark. In 1287, one mark $=214.3 \mathrm{~g}$, cf. Nils Ludvig Rasmussen, "Mark" in Kulturhistorisk leksikon for nordisk middelalder (KLNM) Vol.11:424 and Swen Owe Jansson, "Vikt" in KLNM, Vol. 20 : 58 (Karker et al. 1956-1978).

4 Pellz/pell probably refers to silk fabrics; camelot refers to a woven fabric that might have originally been made of camel or goat's hair, and fustane is a fabric made of cotton. 


\section{Crucifixes and Crosses in Medieval Norway}

When the vicar Nils Sverdrup made an inspection par curiosité of the then damaged cathedral in Hamar in 1707, he revealed that the cathedral's crucifix had a cavity in Christ's head and swamp-like material in the area around the eyes (Hamar-krøniken 1937, pp. 90-91). These features-interpreted by Sverdrup as pia fraus, a pious fraud-testify to a sculpture able to cry, possibly serving as a prop in liturgical plays. The tears may also have been sought for healing of ailments, meaning the crucifix functioned in analogous manner to the more famous miracle-working crucifix in Røldal (c.1250) (Figure 1). Purportedly sweating during Midsummer, the Røldal crucifix caused pilgrims to flock to the mountain church to touch it with linen cloths (Bondevik 1935; Blindheim 2004b).

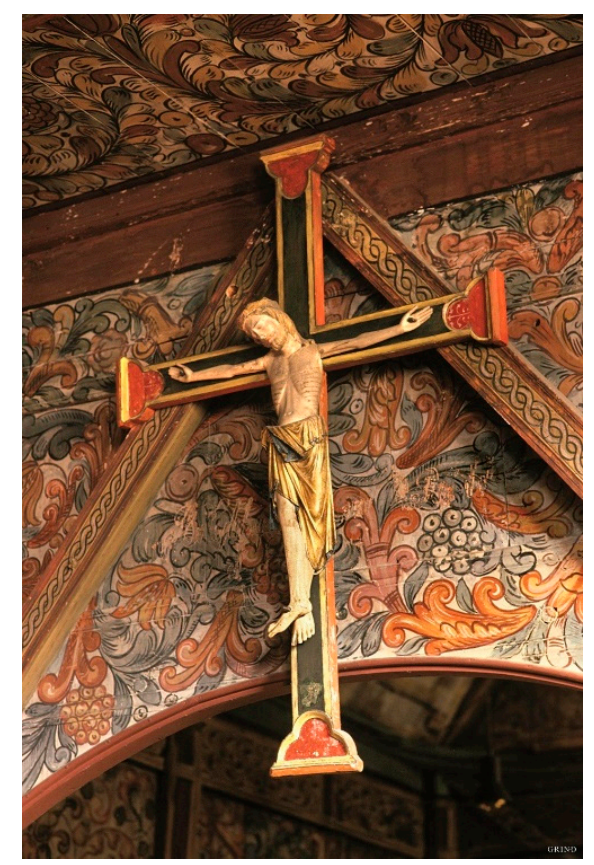

Figure 1. Crucifix from Røldal. Polychrome oak, c.1250. Røldal church. Photo: Svein Nord/Grind.

Triumphal crosses could also work miracles. Although no actual miracles are actually recorded, the large Triumphal Cross (c.1200) in the Borre parish church was a tremendously popular pilgrimage site in medieval Norway (Figure 2). The cross received testamentary gifts (DN 11,41) and was among the holy crosses mentioned as sites that Queen Margrethe (d.1412) wanted to be visited on her behalf after her death, according to a letter from 1405 (Jørgensen 1909, p. 39; Blindheim 2004b). Allegedly, the Borre cross had relics in the form of pieces from the True Cross inserted in the crossing of its wooden structure (Hohler 1994), thus it would be most efficient in bestowing the medieval creation with the features of its holy prototype (Fisher 2006, p. 49). ${ }^{5}$

5 Apart from the two crucifixes in Hamar and Røldal and the Borre cross, there is also a cavity on top of the head and incised tear channels in the figure of St Anne in the late medieval imported sculpture group of Virgin and Child with St Anne (c.1520, of unknown original display, now preserved at the Museum of Cultural Heritage, Oslo), betraying agencies similar to the ones ascribed to the crucifix from Hamar. This perceived animation, however obviously post-date the kinds of devotional activities considered for this essay. 




Figure 2. Triumphal Cross from Borre. Polychrome oak, c.1200. Oslo, Museum of Cultural History, Inv. No. C6130. Photo: Ann-Christine Eek (CC BY-SA 4.0).

Although the crucifixes from Hålandsdalen and Ylmheim are not preserved, more than 100 crucifixes made in Norway between c.1150 and c.1350 are still extant (Blindheim 1998; Blindheim 2004a; Brendalsmo et al. 2001). Some of these are still in situ, and others are in museum collections. Differing in style, material and iconography as well as in the amount of gilding and polychromy, they all share the feature of not comprising silver arm rings or other kinds of jewellery. Moreover, due to repainting and even replacement of arms, they hardly betray any traces of such accessories. The crucifix from Dal (c.1225-50) is remarkable in having shoes, a belt with a buckle, gloves and bracelets all painted in red bolus with black contours; the bracelet on Christ's right arm is both carved and painted (Figure 3). A mutilated crucifix from Sandeid has traces of similar decoration, one bracelet around the arm and one around the wrist. (Figure 4). The crucifix from Aulstad (c.1250) could be indicative, too. Placed within a circular frame, the Christ figure has one cut in the elbow area on each arm, which may correspond to the position of actual silver rings, although differing from the carved or painted bracelets in the Christ figures from Dal and Sandeid (Figure 5).

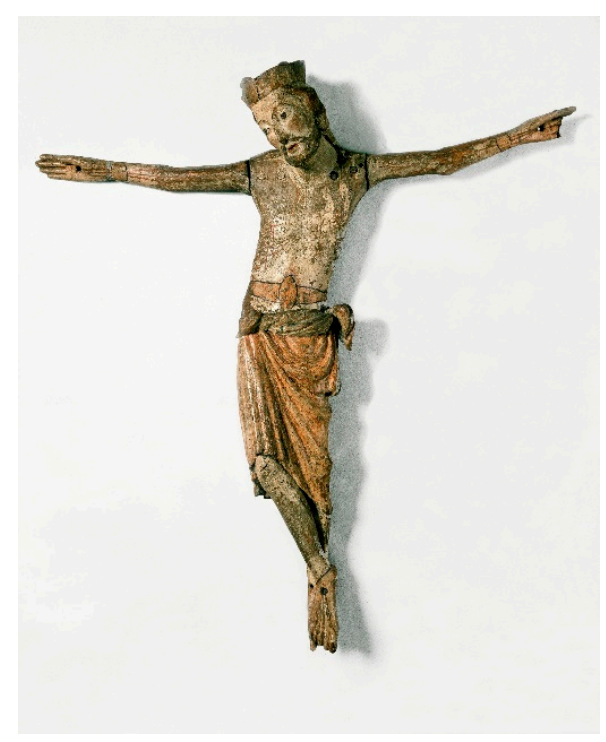

Figure 3. Crucifix from Dal. Polychrome oak. Polychrome oak, 1225-50. Oslo, Museum of Cultural History, Inv. No. C6130. Photo: Eirik Irgens Johnsen (CC BY-SA 4.0). 


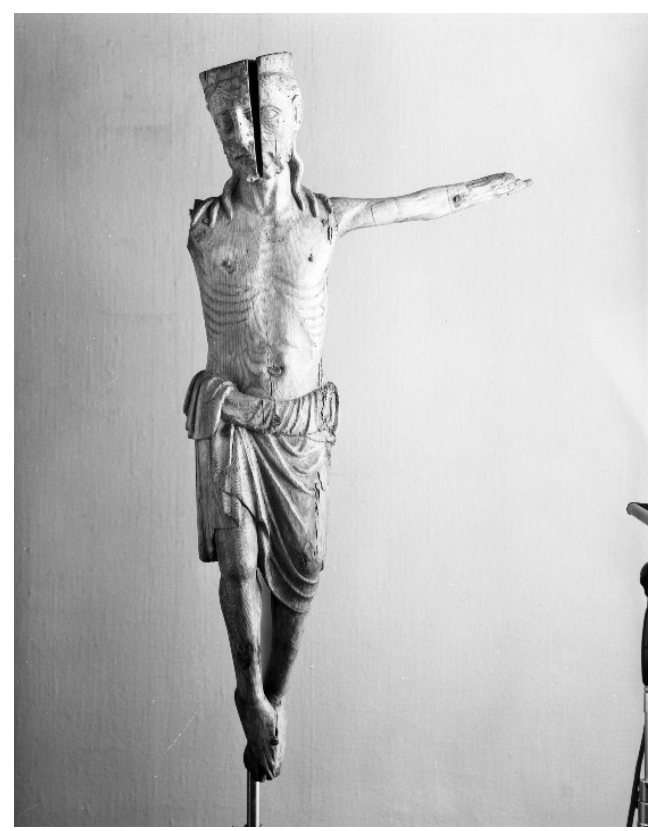

Figure 4. Crucifix from Sandeid. Polychrome birch, 1225-1250. Bergen, University Museum. Photo: Ørnulf Hjort-Sørensen (CC BY-SA 4.0).

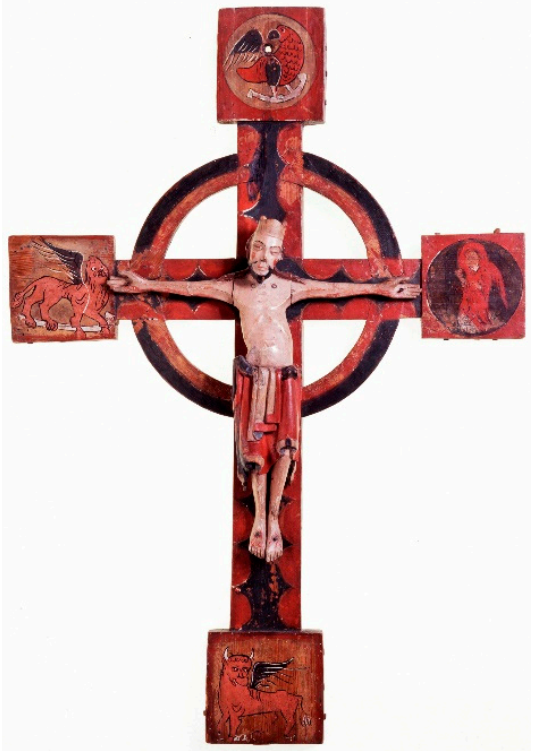

Figure 5. Crucifix from Aulstad. Polychrome oak, 1200-1220. Oslo, Museum of Cultural History, Inv. No. C33287. Photo: Erik Irgens Johnsen (CC BY-SA 4.0).

The Sandeid crucifix also wears carved shoes and there are remnants of metallic shoes on the crucifix from Gjerstad (Jernæs 2016, p. 14). Shoes also appear on a handful of crucifixes from medieval Sweden, namely Säterbo, Kiaby, Linde, Anga and Stenkumla (Blindheim 1986, p. 84). Moreover, a crucifix in Kliplev in Denmark, referred to as St Saviour in Queen Margrethe's letter, but only known from post-medieval descriptions, apparently had a crown of gold as well as golden gloves and shoes (Jørgensen 1909, p. 40). Shoes are also found on the Volto Santo in Lucca and the many replicas of it. It is difficult to tell how the pæll in Ylmheim was arranged; it may have formed part of the loincloth drapery or made up a full liturgical vestment similar to the painted tunica found in the mid- to late twelfth-century crucifixes in places as distant as Väversunda in Sweden and the region of Ripollès in Catalonia (Kroesen et al. 2019, pp. 138-40). A small crucifix from Limoges found in Oslo also wears 
tunic (Figure 6). ${ }^{6}$ Whereas shoes, loincloths or liturgical vestments feature in crucifixes in various parts of Europe, the painted/carved insignia of Dal and Sandeid—and the silver bracelets indicated as parts on the now lost crucifixes in Hålandsdalen and Ylmheim—have no equals neither in Scandinavia nor in Europe.



Figure 6. Limoges crucifix. 13th century. Oslo. Museum of Cultural History. Inv. No. 21300. Photo: Not identified (CC BY-SA 4.0).

Before turning to medieval devotion to the cross and/or to crucifixes, a few small scale metal crucifixes pre-dating the inventories by two centuries will be brought into the discussion insofar as they are material witnesses to early medieval practices of sculpture embellishments. The Birka-crucifix (Figure 7), a silver filigree pendant from the tenth century, is allegedly the oldest representation of Christ in Scandinavia. It was found in a grave in 1879. Due to the materials employed, it is difficult to decipher if the rings on the arms are intended as bracelets, as part of an intentional clothing, or if they facilitated the inclusion of fingers (Staecker 1999, pp. 491-93). They may even indicate that Christ was tied to the cross in the same way as does the rings on the pendant crucifix from Lilla Klintegårda indicate (Staecker 1999, p. 478). Two eleventh century pendants found in Trondheim are equally elusive, yet the one with a less static pattern could have intentionally been shaped as a crucifix with bracelets (Figure 8). The Danish Åby-crucifix, made of wood and gilded bronze around 1100, has no signs of bracelets, but it clearly wears a large collar (Figure 9), thereby indicating crucifixes could at times be invested with jewellery. Or, more specifically, it indicates accessories in the form of jewellery could be included as an integral part of a gilded crucifix. A conceptual correspondence between the collar and the silver bracelets in Hålandsdalen and Ylmheim would thus suggest that the silver bracelets were of an inalienable nature, included as part of the polychromy and the gilding.

6 Post-dating the inventories, two entries from the Icelandic diploma allows us to identify two crucifixes in the church of St Mary at Alftanes, "one cross dressed and one undressed» (1354) and one in Vallanes which was fitted with a suitable chasuble and amictus (1448). 


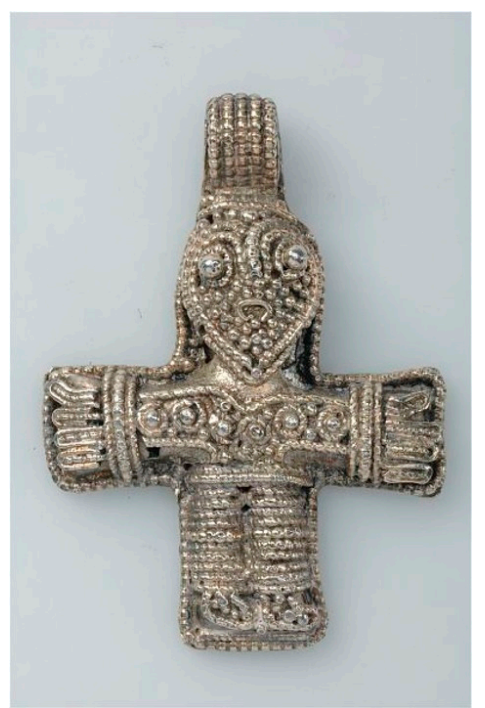

Figure 7. Crucifix from Birka. Silver pendant, 9th century. Stockholm, SHM, Inv. No. 34 000. Photo: Gabriel Hildebrand (CC BY 2.5. SE).



Figure 8. Crucifixes from Trondheim. Silver pendants, 11th century. Trondheim, NTNU University Museum, Inv. No. T16978A and T16978B. Photo: Per E. Fredriksen.

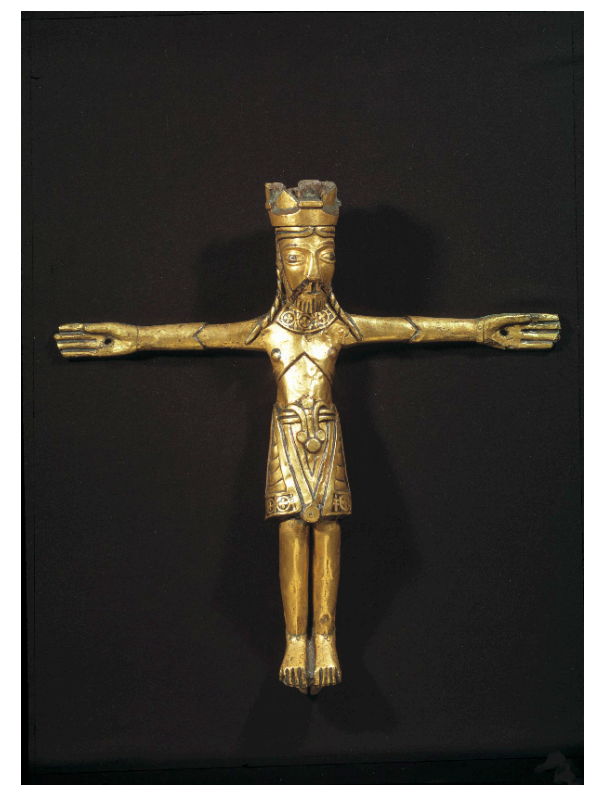

Figure 9. Crucifix from Åby. Gilded silver on wood, c.1100. Copenhagen, National Museum of Denmark, Inv. No. D629. Photo: Lennart Larsen (CC BY SA). 
We cannot exclude the possibility that the silver bracelets were included as modest attempts of investing the two crucifixes with the same delight of sensory experience as was the collar on the Åby crucifix. Such delight is known also in the form of multi-coloured gems on early medieval processional crosses, such as the ones known as the Cross of Justin II, the Desiderius Cross and the Lothair Cross, or even the now lost cross from Saint-Denis, eulogized by Abbed Suger in his De Adminastrione (Carruthers 2013, pp. 39-41). It is more likely, however, that the bracelets were a post-productional, alienable addition. Indeed, even the painted and carved bracelets in Dal appears as being secondary to the Christ-figure itself. The silver brooch (silfr sylgia) mentioned as part of the Calvary group (the crucifix with the Virgin and St John) in Hålandsdalen appears to be alienable, too. Medieval costume tradition in general and the placement of brooches made of rock crystal or polished glass, for example the ones incorporated in the Virgin in the golden altar from Lisbjerg (c.1100) or the Grong Madonna (13th century, Figure 10), suggest the silver brooch on the Calvary group in Hålandsdalen was positioned on the chest of the Virgin.

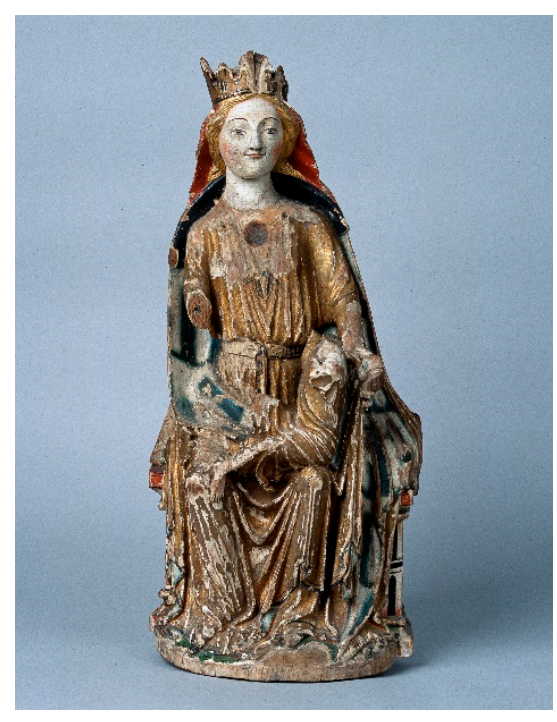

Figure 10. Madonna from Grong. Polychrome oak, 13th century. Trondheim, NTNU University Museum, Inv. No. T1947. Photo: Per E. Fredriksen (CC BY-SA 4.0).

\section{Medieval Devotion to the Cross}

The liturgy of the medieval parish church was codified in the Latin West in the early 13th century, emphasizing the doctrine of the transubstantiation established in 1215. The ritual space where all celebrations took place followed suit in order for ecclesiastics to better communicate the significance of the Eucharist (Rubin 1991; Catto 2000). The liturgical centrality of the crucifix in the church would also prevail also in the following centuries, although in terms of image devotion, a number of complementing devotional practices revolving around images appeared from the late fourteenth century onwards. These practices were often related to private prayer and indulgences and favoured images such as the Man of Sorrows, the Wounds of Christ and the Virgin of the Rosary (Belting 1981; Ringbom 1984; Duffy 1992; Van Os et al. 1994; Kaspersen and Hastrup 2004; Marks 2004; Skinnebach and Laugerud 2007; Laugerud et al. 2016; Blick 2019).

In the Old-English Poem The Dream of the Rood, however, the Cross is the protagonist, the victory-beam into which the narrator trusts his hope of protection, assured that devotion to the Cross or crucifix would ensure entry to heaven. The poem has been situated in connection to liturgical drama, such as the Easter Adoratio Crucis from the Winchester Regularis Concórdia (c.973) (Holloway 1984; Ó Carragáin 2005). Applied for the celebration of Good Friday, the liturgy was also adopted in Norway as attested by two preserved twelfth-century manuscript fragments in the University Library in Bergen, the Mi 12 and the MS 1549, 2 (Gjerløw 1970). It is very likely the ritual was still current in 
the early fourteenth century and celebrated in Hålandsdalen and Ylmheim alike, yet in a style more suitable for smaller parish churches (Helander 2001).

Moreover, as the cross was both the instrument of Christ's death as well as the bringer of eternal life, in sculptural form crucifixes would serve "as paths of divine power of those who venerated them" (Smith et al. 2001, p. 599). The very famous Volto Santo in the cathedral of Lucca cathedral (Figures 11 and 12) is but one of many medieval crosses on public display that offered paths of divine power and generated fervent devotion. It is included here not as an example of an animated crucifix or as a prop in religious processions, but as a reference point for continental devotion to the cross as the Volto Santo proper and its miraculous capacities were known also in fourteenth-century Scandinavia.

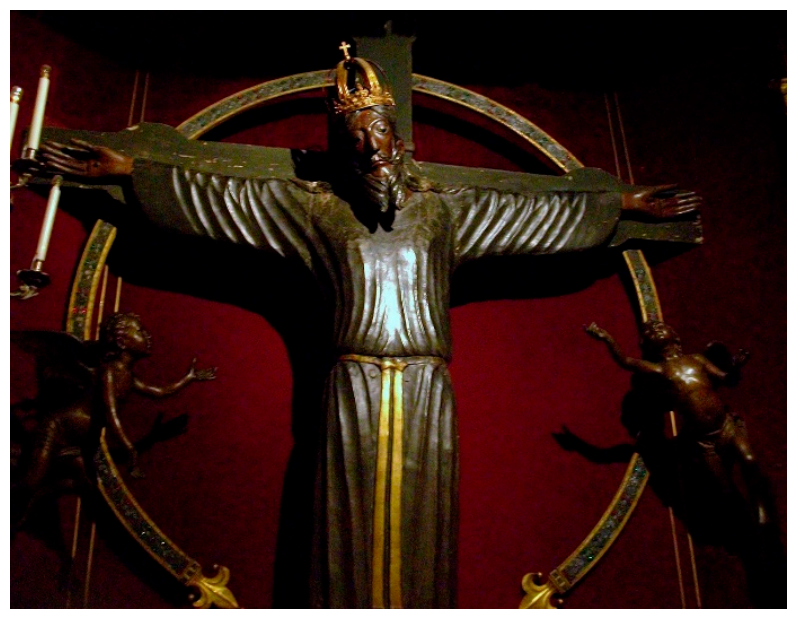

Figure 11. The Volto Santo. Polychrome wood, c.1200. Lucca cathedral. Photo: Wikipedia Commons.

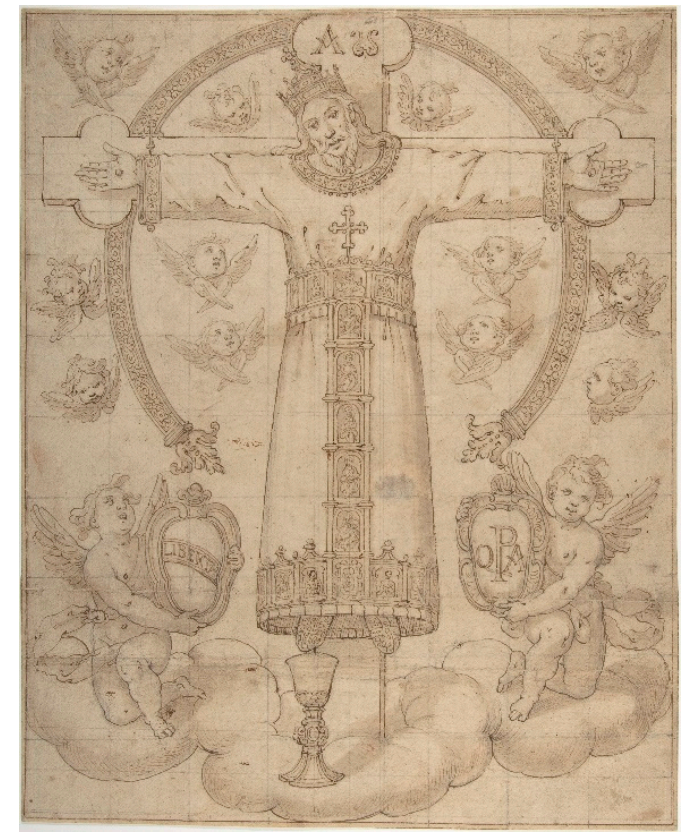

Figure 12. The Volto Santo in Lucca cathedral. Anonymous artist. Drawing, 16th century. New York, The Metropolitan Museum of Art, Inv. No. 61.211. Photo: The Metropolitan Museum of Art/Creative Commons.

Enjoying great popularity from the end of the eleventh century, possibly occasioned by the consecration of the rebuilt cathedral in 1070, the legend has it that the Volto Santo is an acheiropoietoi, an object not made by human hands. The present crucifix, however, is thought to have been carved by an artist from the circle of Benedetto Antelami around the turn of the thirteenth century. The Christ 
figure is of the triumphant type, accentuating the majestic, royal and divine aspects of Christ at the expense of his suffering and human nature. There is a cavity between the shoulders at the back, which, according to the Leobinus legend, previously held a portion of the Crown of Thorns, Christ's sudarium and an ampulla with Christ's blood. The miracle-working potential of the Volto Santo stemmed both from the crucifix being a true image and from its reliquary aspect (Kurz 1997; Il Volto Santo 2003; Matyjaszkiewicz 2018). The crucifix itself and illustrations telling the legend of its arrival in Lucca were both widely diffused from the turn of the fourteenth century to large parts of Europe (Martinelli 2016). Jean-Claude Schmitt has even proposed that the diffusion of the crucifix allowed for the sculpted simulacrum of Christ's true face image to be repeatedly recreated in a manner similar to the way the consecrated host constantly transubstantiates into the body of Christ (Schmitt 1995).

The distance between Lucca and the parish churches in Hålandsdalen and Ylmheim may seem too far for the former to have been able to influence the perception of crucifixes as clothed and/or miracle-working sculptures in the latter two. Nevertheless, the cathedral and the Volto Santo would have been known in the Nidaróss archbishopric at the time when the crucifixes were carved and the inventories were written as they are both mentioned in the Leiðarvisir, an itinerarium compiled by Nikulás Bergsson after a pilgrimage from Iceland to the Holy Land. The pilgrimage took place in the earlier parts of the 1150s. Nikúlas returned to Iceland in 1154 and became abbot at Munkapverá the following year. Listing the various places one would stop along the route, and the distances between them, the itinerarium also contains a mix of Christian themes and pagan legends. From the cathedral in Lucca, Nikúlas highlights the crucifix: “( . . ) the crucifix made by Nicodemus from Christ's true face; the crucifix has spoken twice; one time it offered shoes to a poor man and another time it testified on behalf of an accused man" (Symbolae 1832, p. 20). ${ }^{7}$ Nikulas also mentions his compatriots' involvement in the city: "He [king Eiríkr] left an endowment in Lucca, so that anyone speaking Nordic languages could drink fully and freely, and he built a hospice eight miles south of Piacenza, where they could refresh themselves" (Symbolae 1832, pp. 27-28). ${ }^{8}$

As it were, Nikulas transferred knowledge of the cathedral Lucca, the Volto Santo and two miracles evoked by it and encouraged his countrymen to travel there, advocating the hospitality everyone speaking Danish would receive. It is probably this house or one of similar status that is mentioned in a letter from Pope Martin V to Archbishop Jon Raude in 1282 (DN 6, 46). Unfortunately, there is no information in the travelogue about how devotional acts would take place in its vicinity. Nonetheless, information about later indulgences such as the 40 days indulgence granted by Bishop Enrico in 1309 and contemporary devotional activities in the form of money and material goods given to support the maintenance of the cathedral and the chapel (Il Volto Santo 2003, pp. 131-72; Matyjaszkiewicz 2018) may have spread north as connections between Lucca and Norway continued in the thirteenth and fourteenth century (DN 19, 322; DN 19, 325 and others). The shoes found on some of the Scandinavian crucifixes may relate to the shoes on the Volto Santo, either as they come fore in visual replicas spreading from the early fourteenth century or through the diffusion of texts telling the miracle stories.

\section{Arm Ring Symbolism and Miracle Working Crosses in Old Norse Texts}

In her book Medieval Life: Archaeology and the Life Course, Roberta Gilchrist has appropriately evidenced how domestic settings housed a wide range of material objects with religious content, for example clasps from prayer books, spoons and brooches with inscriptions, pendants and rings. Many of these objects also have inscriptions and were to be carried close to the body (pendants), or to be

7 Dagför or Lunu til Luku; par er Biskopsstoll at Mario kirkiu [i.e., San Martino], par er roda su er Nichodemus let gera eptir Gudi sialfum; hon hefir ii. sinnum mælt, annat sinn gaf hon sko sin aumun manni, enn annat sinn bar hon vitni rægdum mann.

8 Hann Eirikr Danakonungr Sveinsson lagdi fé til i Luku, at, hverr madr skylldi drecka vin okeypiss ... einu af danski tunugu ok hann let gera spital viii milum sudr fra Plazinzoborg. 
momentarily close to the body as utility goods (spoons, jugs) (Gilchrist 2012, pp. 154-68). Excavations from Perth have shown similar patterns of dispatched items with religious content in household areas (Hall 2011). On the other hand, presumably secular items may have been invested with religious meaning in ways similar to how objects such as swords were considered as animate in certain contexts in the Late Iron and Viking Ages (Lund 2017 with references). For this article, arm rings and golden rings are important cases in point.

What did it mean to have a ring around one's arm? In Viking Age Scandinavia, arm rings in precious metal were both a symbol of power and a payment method. Dated to the third quarter of the ninth-century, the Hoen hoard demonstrates some of the richness and typologies of Viking metalwork, containing one necklace, two neck-rings, three arm-rings, one finger-ring and a brooch formed of a reused strap mount (Fuglesang and Wilson 2006). From the Old Norse sagas we know of several examples of arm rings used by the one exercising power. In the Saga of the Ere-Dwellers, the events unfold at the end of the 10th and the beginning of the 11th centuries (written down only in the 13th century), Thorolf erects a house on Iceland and "off the inmost house was there another house, of that fashion whereof now is the choir of a church, and there stood a stall in the midst of the floor in the fashion of an altar, and thereon lay a ring without a join that weighed twenty ounces, and on that must men swear all oaths; and that ring must the chief have on his arm at all man-motes" (The Saga of the Ere-Dwellers, chapter 4). Arm rings are also mentioned in the scene when Gudleif and his men are allowed to leave the land onto which they sailed without cause "and or ever he and Gudleif parted, he drew a gold ring from off his arm, and gave it into Gudleif's hand, and therewithal a good sword, and then spake to Gudleif: 'If it befall thee to come back to thy fosterland, then shalt thou deliver this sword to that Kiartan, the goodman at Frodiswater; but the ring to Thurid his mother'" (Saga of the Ere-Dwellers, chapter 64).

From medieval Norway, arm rings appear, for example in Fagrskinna, the genealogical enumerating of Norwegian kings (written around 1220). "Now there came to light a lump of gold as big as a man's head. King Haraldr took it up and said: 'Kinsman, where is the gold to be exchanged for this knob?' Then the king replied, 'Unrest and heavy levies have brought it about that almost all the gold and silver has been given to the retainers, and now there is no more gold in my possession than this ring,' and he took it from his arm and gave it to Haraldr" (Fagrskinna 2004, p. 196). Arm rings were among the foremost symbols of worldly power whereas finger rings were given as gifts. Archaeological evidence sustains these assumptions in as far as rings prefigure more often in graves (Staecker 2006; Glørstad and Wenn 2017).

Miracle-working crosses are also known from the Old Norse saga literature. A relic from the Holy Cross was brought to the north by King Sigurðr which he placed in a church he erected in Konungahella (Magnússona saga 2015, pp. 156-57). Consecrated when Sigurðr had been king for twenty-four years, Krosskirkja was consecrated and embellished with a golden altar frontal (Magnússona saga 2015, p. 169). During an attack by Wendish forces led by King Réttiburr, the church was sacked and burnt; yet, the priest Andreas was allowed to keep the Holy Cross and some other valuable items. When the heathen parted, however, they were struck with fear by a portent as the priest had appeared with the Holy Cross, explaining: "And there is so much power in the Cross that such miracles have often taken place upon heathens, in some cases much plainer ones, when they have taken it in their hands" (Magnúss saga blinda 2015, p. 181).

In addition to saga literature, there are also traces of both power structure and divine power in sacred texts. The Old Norse Homily book was written around 1200 in Bergen, possibly at the cathedral chapter. Given its content, it is now better considered a homiletic handbook, its content often being more similar to sermons; sermons for both the Feast Days concerning the Cross-the Invention of the Cross (3 May) and the Exaltation of the Cross (14 September)-are included. From the Invention of the Cross, the sermon concludes with the following lines:

The Holy Cross is a shield for all danger, support for all misery, in sorrow it is a comfort and in joy an encouragement for the good; it is protection from danger, healing from ailment 
liberation from all ties, counsel from sin, victory in battle, strength against temptation, powerful for the poor and a chieftain for the powerful (stjórn auðigra) (...). All this is due to God's mercy, for the one who on the Cross redeemed mankind from death-Jesus Christ. Him be praised with the Father and the Holy Spirit per omnia saecula saeculorum amen.

(Gammelnorsk homiliebok, 109)

The section does mention an array of the functional uses of a cross. The reference to Christ as the 'chieftain of the powerful' (stjórn auðigra) is compelling as it seemingly integrates the ruling aspect of Old Norse society in a text legislated by the church. Nevertheless, Christian ideas would also occasionally occur in the literary production of Snorri Sturlusson and other thirteenth-century writers, even if sagas in general maintained the societal values emphasized in Old Norse literature (Bagge 1998, pp. 66-69; Bagge 2010, p. 153). The silver bracelets, therefore, could be considered a materialized coupling of the two cosmologies' ruling systems in visual terms, and the power symbols of chieftain may have been recognised as such when attached to the Christ figure on the cross.

Due to the dates given in the inventories, the crucifixes with silver bracelets must pre-date 1306 and 1321 respectively. It is thus likely that the crucifixes would have been similar to the Dal, Sanneid or Aulstad ones, having the Christ figure standing upright with parallel legs, one nail in each foot, arms horizontally stretched to either side and carrying a crown; that is as Christus triumphans, as the victorious king. Accordingly, Blindheim considered the insignia of Dal and Sandeid as reflecting practices related to contemporary kings, that is the investiture of insignia at the coronations of Norwegian kings in the second half of the 12th and the first half of the 13th centuries (Blindheim 1986, p. 90). The material value and mobility of the silver bracelets, however, allow for further interpretations. Even if the silver items did indeed reflect the coronation of a king, the act of placing the items on the arms of Christ may still have been a devotional act.

\section{Silver Bracelets-Devotion, Gifts and Gender}

As it were, material gifts were often offered to sculptures in churches as pious donations and according to contemporary wills, predominantly by female testators. In 1325, a Tournois woman stated in her will that she wanted "my good tissue to care for the image of Notre-Dame in Tournai." ${ }^{\prime 9}$ Richard Trexler almost laconically notes this kind of testamentary gift "n'est pas atypique" (Trexler 1991, p. 196) and a similar pattern of pious bequests in wills can be traced across medieval and early modern Europe (Howell 1996; Kamerick 2002, pp. 69-105; Marks 2004, pp. 183-85; French 2008; Jürgensen 2018, pp. 501-12). In her work on English parish churches, Katherine L. French has analysed not only wills, but also churchwarden accounts and guild accounts. Her findings, too, proved women's relation to the parish to be structured by their ability to offer their labour and donate household goods such as clothing, jewellery and knives (French 2008, pp. 37-48).

Also from medieval Norway a few practices come to light, although from a slightly later date than the inventories. In 1349, a woman called Ingebjørg Munansdatter donated a headscarf (velum), not to her parish church but to the Munkeliv monastery, in order for the convent to be able to wrap God's body (DN 11, 7). It has been suggested this textile was a Hungertuch, intended to cover the crucifix during Lent as the sight was supposed to abstain from bodily participation in the divine pleasures during this observance (Stang 2015, p. 151). It could, however, be Ingebjørg was actually donating a corporal, a cloth intended to cover the host. As testified by the inventories from Hålandsdalen and Ylmheim, the majority of the entries concern textiles. In a will dated 14 July 1400, however, Jon Marteinsson had a sculpture of St Lawrence in Foss Church and a sculpture of St Margaret in Lund church "coloured," probably meaning that he paid for the repainting or refurbishing of two sculptures worn and torn (Stang 2015, p. 152). These two documents alone cannot be given statistic value, but as

9 "Men boin tissut pour caindre de ymagène Notre-Dame di Tournay." 
it happens, they are in agreement with the late medieval European trend of complementing devotional gifts to the cross or to Christ's body with donations to images of saints (Marks 2004; French 2008, p. 43).

Caroline Bynum summarized the gendered dynamics of gift-giving as "men gave up money, property and progeny; women gave up food" (Bynum 1988, p. 193). For Ylmheim we are fortunate enough to have a preserved diploma from 1336 evidencing a transaction of lands from a lay person to the church and its priest (DN 15, 16). Similar transactions are preserved for other parishes and priests; most transactions were initiated by men, but there were also a significant number of women who addressed these property issues. Documents from Oslo bishopric, however, show that women gave lands to the chapter and nunneries, whereas men gave properties to parishes, possibly because they were expected to demonstrate their power in their local communities (Emanuelsson 2005; Andersson 2010). From the sources available, people's engagement with their parish include to have sculptures repainted when they were losing colour, to donate velum to protect either the crucifix or the host, and to donate properties. There is not enough surviving evidence to ascertain whether lay people made pious bequests to their parish crucifixes in the form of silver arm rings.

One reason people would give portable wealth such as money, jewellery and items of metal was that these gifts were more flexible than land in as far as they could be bartered, melted down, refashioned or reminted. Moreover, placing family jewellery in the church meant the objects were not available for gift-exchange or trade in the secular sphere and were likewise out of circulation as inter-generational objects. As evidenced in the 1920s by anthropologist Marcel Mauss in his seminal work "Essay sur le don," gift-giving—also when in guise as pious bequest—is as much about reciprocity as about charity (Mauss 1923). Mauss' text paved the way for researchers from a range of academic disciplines in establishing the importance and political statement of gift-giving within different communities across temporary and geographical boundaries. In later anthropological frameworks, reciprocity appears as the more superficial dynamic, whereas the more powerful aspect of gift-giving lies in the politics of "keeping-while-giving" (Weiner 1992), or indeed as "an intimately political and double-faced discourse" (Palsson 2010, p. 24).

In the Saga of the Ere-Dwellers, Thorgunna opts for the keeping-while-giving strategy when dividing her property; and she does so in a manner worth exploring in more detail.

This would I have done: I would be borne to Skalaholt if I die of this sickness, because my mind tells me that that stead will be for one while the most worshipped stead in the land; and I wot also," says she, "that there will be priests to do the singing over me; so I pray thee to bring me there, and of my goods shalt thou [Thorod] have so much as that thou wilt have no loss thereby; but from my undivided goods shall Thurid have the scarlet cloak that I own; and this I do to the end that she may be content that I see to my other goods in such wise as I will; but I will that thou take for the cost thou hast for me that which thou wilt, or that pleases her, from such things alone as I leave thereto. A gold ring I have which shall go to church with me, but I will that my bed and my bed-hangings be burned up with fire, for that they will be of no good to any man; and I say this not because I grudge anyone to enjoy those good things, if I knew that they would be of good avail to any; but now I say so much thereover," says she, "because I deem it ill that folk should have so much heavy trouble from me, as well I wot will be, if ye turn away from that which I now ordain."

(Eyrbyggja saga, chapter 51)

The actual meaning of bringing 'the gold ring to church with her' may be disputed, but it seems likely that she gave it to the church when compared to the many examples of English women giving rings to the parish (French 2008, pp. 48, 67). As such, it was not given to another individual for personal use in the same way as was her scarlet cloak, nor is it decomposed as should be the bed-hangings. It is possible that the silver bracelets documented on the Christ figures on the two crucifixes had, at one point, gone to church upon someone's death, too. The silver bracelets may also have come as part of distributed goods in the manner evidenced in the form of wills and letters (Bagge 2010, p. 
153) - and the brief mention in Grettir's saga "But Thorstein and Spes divided their share of the goods, and some they gave to churches for their souls' health, and some they took with them. Then they betook themselves Romeward, and many folk prayed well for them" (Grettir's saga 1900, chapter 94).

Whereas precious objects were given to the church for spiritual benefits on part of the benefactor, gifts to the images in the church also invested the image with an increased material as well as spiritual value. As posited by Ralph Dekoninck in relation to images of the Virgin, due to the rule of decorum, it is advised not only to honour images of the Virgin but also to embellish them with the most precious objects in order to materially express this honour. Moreover, such honouring practices would partly conceal the more mundane materiality of the sculpture itself (wood), in turn allowing the material surplus (silver bracelets) to enhance the power of the images (Dekoninck 2012, p. 162). Dekoninck thus follows Thomas Golsenne who contended that "[a]dornment does not follow the miracle, but makes possible the belief that a miracle has occurred through a given image" (Golsenne 2010, p. 82).

If the crucifixes in Hålandsdalen and Ylmheim evoked miracles, these were never recorded, neither in public documents nor in local folklore. This silence, however, does not mean the crucifixes were not efficacious for some people asking for assistance, and thus later wishing to reciprocate the crucifixes by having some family valuables given to them. Roberta Gilchrist noted that "People came to believe in the quasi-magical properties of a particular object because it has been consecrated by a priest or had been in close physical proximity to statues of saints" (Gilchrist 2013, p. 179). There is evidence from England that such gifts could periodically be lent back to the domestic sphere, for example as amulets during childbirth (Gilchrist 2013, p. 178), at times even abusing this privilege (French 2008, pp. 31-32), but we lack evidence of similar displacements of objects in medieval Norway. The embellishments of the crucifixes in Ylmheim and Hålandsdalen could thus be considered as domestic devotional interventions in the religious material culture; firstly in order to make the images more powerful in their religious settings, secondly to allow for this power to be deposited to domestic settings when needed. Ultimately, the crucifixes may have been embellished with bracelets and brooches as "decoration is often essential to the psychological functionality of artefacts" (Gell 1998, p. 74). A rather suggestive idea to be drawn from this is that the bracelets-and the brooch-were given to the crucifixes, not only to invest the crucifix itself with power or decorum, but also to have the bracelet receive the already inert power of the crucifix.

\section{Concluding Remarks}

The anonymous compilers who penned down the inventories of Hålandsdalen and Ylmheim both took their time to comment on the silver arm rings adorning the arms of the crucifixes in either church, and also to note that it was a brooch attached to the Virgin in Hålandsdalen. Although the crucifixes themselves have not been preserved for posterity, these entries allow us to deduce that such adornment was once a feature enjoyed by at least these two and probably more crucifixes that were made before 1320. The inventories' rather elusive nature obscures what the full significance of the silver bracelets and the silver brooch were, and our understanding is further complicated by the fact that not only are the crucifixes in question long gone, but also by the fact that none of the preserved crucifixes dating from $c .1150-c .1320$ have silver arm rings around their arms.

Although the inventories offer sparse information about the crucifixes, their appearance, their role in the celebration of Mass and their role in devotional activities may be hypothesized from cross-references with other Norwegian medieval crucifixes known to have been able to cry or to evoke miracles. Furthermore, the painted and carved bracelets on the crucifixes from Dal and Sandeid, as well as the cuts on both arms across the elbow area in the Christ figure on the crucifix from Aulstad, may be taken as material witnesses of the descriptions in the inventories. The extensive and long standing documentation of cultic practices relating to crucifixes elsewhere in the Latin West, such as the Volto Santo in Lucca cathedral, and analogies drawn from devotion to the crucifix and devotion to the cross as implied in Old Norse homiletics, also add to our understanding of the two crucifixes. 
Moreover, analogies with the symbolism of arm rings in saga literature and with the practice of gift-giving and creation of heirlooms and amulets puts the crucifixes into a relief.

The silver bracelets may have been included when the Christ figure was made, as alienable parts of its feature and equal to its polychromy. It seems more likely, however, they were placed there at a later point in time as a way of updating or embellishing the Christ figure, or as a strategy of investing the figure with a powerful symbol from the secular world. They may also have been inalienable, given as gifts or placed on the arms as a way to keep precious objects out of circulation, or to invest them with the spiritual power inherent in the holy sculpture. In as much as they decorated the church interior or the Lord's table, the crucifixes seem to have also acted as keepers of treasures, but there is no way of knowing if the silver items were deliberately relocated to the secular sphere or if they were sold, melted or stolen.

Funding: No external funding was received for the writing of this article.

Acknowledgments: The author would like to thank Salvador Ryan for his encouragement and patience, the anonymous reviewers for their questions and comments, and Ildar Garipzanov, Max Naderer, Ole-Albert Rønning Nordby and Kristina Dziedzic Wright for valuable and much appreciated feedback.

Conflicts of Interest: The author declares no conflict of interest.

\section{References}

\section{Primary Sources}

Diplomatarium Islandicum. 1857-1976. Reykjavik and Copenhagen: Hið íslenska bókmenntafélag. https: //baekur.is/search.

Diplomatarium Norvegicum. 1847-2011. Oslo: Riksarkivet. https://www.dokpro.uio.no/dipl_norv/diplom_felt.html. Fagrskinna: A Catalogue of the Kings of Norway. 2004. Translation and introduction by Alison Finlay. Leiden: Brill. Gammelnorsk homiliebok. 1972. Translation by Astrid Salvesen and introduction and comments by Erik Gunnes. Oslo: Universitetsforlaget.

Leiðarvísir, an Old Norse itinerarium: A Proposal for a New Partial Translation and Some Notes about the Place-Names. Translation and Comments by Luana Giampiccolo. https://skemman.is/bitstream/1946/14573/ 1/Lei\%C3\%B0arv\%C3\%ADsir.pdf.

Grettir's saga. 1900. Translated by William Morris and Eirikr Magnusson. https://sagadb.org/grettis_saga.en.

Hamar-krøniken med andre kilder til kunnskap om det gamle Bispesete ved Mjøsen. 1937. Published by Arne Arnesen. Oslo: Foreningen for Norsk Bokkunst.

Magnússona saga. 2015. In Snorri Sturluson. Heimskringla, Vol. III. Translated by Alison Finlay and Anthony Faulkes. London: University College London, pp. 147-69.

Magnúss saga blinda ok Haralds gilla. 2015. In Snorri Sturluson. Heimskringla, Vol. III. Translated by Alison Finlay and Anthony Faulkes. London: University College London, pp. 170-86.

Páls biskups saga. 1858. In Biskupa sögur. Vol. 1. Copenhagen: Hið íslenska bókmenntafélag, pp. 125-48.

Eyrbyggja saga. 1989. Translated by Hermann Pálsson and Paul Edwards. Harmondsworth: Penguin Classics. Symbolae ad geographiam medii aevi, ex monumentis islandicis. 1832. Publication, introduction and comments by Erik Christian Werlauff. Copenhagen: Gyldendal.

\section{Secondary Sources}

Algazi, Gadi, Valentin Groebner, and Bernhard Jussen. 2003. Negotiating the Gift: Pre-Modern Figurations of Exchange. Göttingen: Vandenhoeck and Ruprecht.

Andersson, Catharina. 2010. Andliga gåvor i världsligt bruk-Om den religiösa gåvan som social och maktskapande handling [Spiritual gifts in secular contexts—About the religious gift as social and powerful act]. In Gaver, Ritualer, Konflikter. Et Rettsantropologisk Perspektiv på Nordisk Middelalderhistorie [Gifts, Rituals, Conflicts. An Anthropological Perspective on Nordic Medieval History]. Edited by Hans Jacob Orning, Kim Esmark and Lars Hermansson. Bergen: Fagbokforlaget, pp. 39-75. 
Bagge, Sverre. 1998. Mennesket i middelalderens Norge: Tanker, tro og Holdninger 1000-1300 [People in medieval Norway: Thoughts, belief and attitudes 1000-1300]. Oslo: Aschehoug.

Bagge, Sverre. 2010. From Viking Stronghold to Christian Kingdom. State Formation in Norway, c. 900-1350. Copenhagen: Museum Tusculanums Forlag.

Belting, Hans. 1981. Das Bild un sein Publikum. Form und Funktion früher Bildtafeln der Passion [Likeness and Presence: A History of the Image before the Era of Art]. Berlin: Mann Verlag.

Blick, Sarah. 2019. Bringing Pilgrimage Home: The Production, Iconography, and Domestic Use of Late-Medieval Devotional Objects by Ordinary People. Religions 10: 392. [CrossRef]

Blindheim, Martin. 1986. Skandinaviske krusifiks med verdighetstegn [Scandinavian crucifixes with insignia]. In Festskrift til Martin Blindheim [Tributes to Martin Blindheim]. Edited by Irmelin Martens, Bjørn Myhre, Eldrid Straume, Per Jonas Nordhagen and Erla Hohler. Oslo: Universitetets Oldsaksamling.

Blindheim, Martin. 1998. Painted Wooden Sculpture in Norway c.1100-1250. Oslo: Scandinavian University Press. Blindheim, Martin. 2004a. Gothic Painted Wooden Sculpture in Norway 1220-1350. Oslo: Messel forlag.

Blindheim, Martin. 2004b. The Cult of Medieval Wooden Sculptures in Post-Reformation Norway. In Images of Cult and Devotion: Function and Reception of Images in Medieval and Post-Medieval Europe. Edited by Søren Kaspersen and Ulla Hastrup. Copenhagen: Museum Tusculanum Press, pp. 47-59.

Bondevik, Kjell. 1935. Valfarting og lovnader [Pilgrimage and promises]. In Museet $i$ Haugesund: 10 års melding 1925-1935 og avhandlinger om vest-norsk kultur [Haugesund Museum: A Report after 10 Years 1925-1935 and Essays on the Culture of Western Norway]. Edited by Heming Skre, C. Magne Rønnevik and John A. Døsseland. Bergen: John Griegs boktrykkeri, pp. 65-77.

Brendalsmo, Jan, Tine Frøysaker, and Jørgen H. Jensenius. 2001. Kors og krusifiks: tre utsnitt av deres historie [Crosses and crucifixes: three aspects of their history]. Oslo: NIKU.

Brundin, Abigail, Deborah Howard, and Mary Laven. 2018. The Sacred Home in Renaissance Italy. Oxford: Oxford University Press.

Bynum, Caroline Walker. 1988. Holy Feast and Holy Fast: The Religious Significance of Food to Medieval Women. Oakland: University of California Press.

Bynum, Caroline Walker. 2011. Christian Materiality: An Essay on Religion in Late Medieval Europe. New York: Zone Books.

Carruthers, Mary. 2013. The Experience of Beauty in the Middle Ages. Oxford: Oxford University Press.

Catto, Jeremy. 2000. Currents of Religious Thought and Expression. In The New Cambridge Medieval History. Volume VI c.1300-1415. Edited by Michael Jones. Cambridge: Cambridge University Press, pp. 42-65.

Corry, Mary, Marco Faini, and Alessia Meneghin. 2018. Domestic Devotions in Early Modern Italy. Leiden: Brill.

Dekoninck, Ralph. 2012. Between denial and exaltation: The materials of the miraculous images of the Virgin in the Southern Netherlands during the seventeenth century. In Meaning in Materials, 1400-1800 (Netherlandish Yearbook for Art History 62). Edited by Ann-Sophie Lehmann, Frits Scholten and H. Perry Chapman. Leiden and Boston: Brill, pp. 148-75.

Duffy, Eamon. 1992. The Stripping of the Altars: Traditional Religion in England 1400-1580. New Haven and London: Yale University Press.

Emanuelsson, Anders. 2005. Kyrkojorden och dess Ursprung. Oslo Biskopsdöme Perioden ca. 1000-ca. 1400 [The Church Land and its Origin: Oslo Bishopric c.1000-c.1400]. Göteborg: Göteborgs universitet.

Fisher, Annika Elisabeth. 2006. Cross Altar and Crucifix in Ottonian Cologne: Past Narrative, Present Ritual, Future Resurrection. In Decorating the Lord's Table: On the Dynamics between Image and Altar in the Middle Ages. Edited by Søren Kaspersen and Erik Thunø. Copenhagen: Museum Tusculanum Press, pp. 43-62.

Freedberg, David. 1989. The Power of Images: Studies in the History and Theory of Response. Chicago and London: The University of Chicago Press.

French, Katherine L. 2008. The Good Women of the Parish: Gender and Religion after the Black Death. Philadelphia: University of Pennsylvania Press.

Fuglesang, Signe Horn, and David Wilson. 2006. The Hoen Hoard: A Viking Gold Treasure of the Ninth-Century. Rome: Bardi Editore.

Gell, Alfred. 1998. Art and Agency: An Anthropological Theory. Oxford: Clarendon.

Genovese, Valeria. 2011. Statue vestite e snodate. Un percorso [The Dressing and Undressing of Statues. An Outline]. Pisa: Edizione della Normale.

Gilchrist, Roberta. 2012. Medieval Life: Archaeology and the Life Course. London: Boydell Press. 
Gilchrist, Roberta. 2013. The Materiality of Medieval Heirlooms: From biographical to sacred objects. In Mobility, Meaning and Transformations of Things: Shifting Contexts of Material Culture through Time and Space. Edited by Hans Peter Hahn and Hadas Weis. Oxford and Oakvill: Oxbow Books, pp. 170-82.

Gjerløw, Lilli. 1970. Missaler brukt i Bjørgvin bispedømme fra misjonstiden til Nidarosordinariet [Missals used in Bjørgvin bishopric from the time of missionaries to the Nidaross ordinarium]. In Bjørgvin bispestol: Byen og bispedømmet [Bjørgvin: The City and the Bishopric]. Edited by Per Juvkam. Bergen: Universitetsforlaget, pp. 73-115.

Golsenne, Thomas. 2010. Parure et culte [Orament and cult]. In La Performance des Images [The Performance of Images]. Edited by Alain Dierkens, Gil Bartholeyns and Thomas Golsenne. Brussels: Éditions de l'université de Bruxelles, pp. 71-84.

Glørstad, Zanette T., and Camilla C. Wenn. 2017. A view from the valley: Langeid in Setesdal, South Norway-A Viking Age trade station along a mercantile highway. In Viking-Age Transformations: Trade, Craft and Resources in Western Scandinavia. Edited by Zanette T. Glørstad and Kjetil Loftsgarden. London: Routledge, pp. 191-211.

Helander, Sven. 2001. The liturgical profile of the parish church in medieval Sweden. In The Liturgy of the Medieval Church. Edited by Thomas J. Heffernan and E. Ann Matter. Kalamazoo: Michigan University Press, pp. $146-86$.

Hohler, Erla Bergendahl. 1994. Borre-korset [The Holy Cross from Borre]. In Fra hammer til kors: 1000 år med kristendom. Brytningstid i Viken [From Hammer to Cross: 1000 Years of Christianity. Transitional Times in Viken]. Edited by Knut B. Bjerva and Jan Ingar Hansen. Oslo: Schibsted, pp. 173-82.

Hoff, Anne Marta. 1997. Holdhus kyrkje. In Norges kirker: Hordaland [Churches in Norway: Hordaland]. Edited by Hans Emil Lidén, Anne Marta Hoff and Ola Storsletten. Oslo: Land og kirke, Volume 2, pp. 8-24.

Holloway, Julia Bolton. 1984. The Dream of the Rood and Liturgical Drama. Comparative Drama 18: 19-37. [CrossRef]

Howell, Martha C. 1996. Fixing Movables: Gifts by Testament in Late Medieval Douai. Past and Present 150: 3-45. [CrossRef]

Jernæs, Nina Kjølsen. 2016. Tre middelalderskulpturer fra A 265 Gjerstad kirke. Undersøkelse og behandling av et krusifiks og to helgenskulpturer [Three Medieval Sculptures from A 265 Gjerstad Church. Examination and Treatment of one Crucifix and Two Saints]. Oslo: NIKU.

Jürgensen, Martin Wangsgaard. 2018. Ritual and Art across the Danish Reformation: Changing Interiors of Village Churches 1450-1600. Turnhout: Brepols.

Jørgensen, Ellen. 1909. Helgendyrkelse i Danmark: Studie over kirkekultur og kirkeligt liv fra det 11te aarhundredes midte til Reformationen [Veneration of Saints in Denmark. Essays in Culture and Religious Life from the Mid-11th Century to the Reformation]. Copenhagen: H. Hagerups Forlag.

Kamerick, Kathleen. 2002. Popular Piety and Art in the Late Middle Ages: Image Worship and Idolatry in England 1300-1500. London: Palgrave.

Kaspersen, Søren, and Ulla Hastrup. 2004. Images of Cult and Devotion: Function and Reception of Images in Medieval and Post-Medieval Europe. Copenhagen: Museum Tusculanum Press.

Keane, Marguerite. 2016. Material Culture and Queenship in 14th-century France: The Testament of Blanche of Navarre (1331-1398). Leiden: Brill.

Kirby, Jo, Susie Nash, and Joanna Cannon. 2010. Trade in Artists' Materials: Markets and Commerce in Europe to 1700. London: Archetype.

Kopania, Kamil. 2010. Animated Sculptures of the Crucified Christ in the Religious Culture of the Latin Middle Ages. Warsaw: Neriton.

Kroesen, Justin, Micha Leeflang, and Marc Sureda i Jubany. 2019. North E South. Medieval Art from Norway and Catalonia 1100-1350. Zwolle: WBOOKS.

Karker, Allan, Helge Pohjolan-Pirhonen, Magnús Már Lárusson, Finn Hødnebø, and John Granlund, eds. 1956-1978. Kulturhistorisk leksikon for nordisk middelalder (KLNM) [Lexicon of the Cultural History of the Nordis Middle Ages]. Copenhagen: Rosenkilde and Bagger.

Kurz, Herbert. 1997. Der Volto Santo von Lucca: Ikonographie und Funktion des Kruzifixus in der gegürteten Tunika im 11. Jahrhundert [The Volto Santo from Lucca. Iconography and Function of the Crucifix with Belt and Tunic in the 11th Century]. Regensburg: Roderer Verlag.

Laugerud, Henning, Salvador Ryan, and Laura Katrine Skinnebach. 2016. The Materiality of Devotion in Late Medieval Northern Europe: Images, Objects and Practices. Dublin: Four Courts Press. 
Lohfert Jørgensen, Hans Henrik. 2017. Live Matter and Living Images: Towards a Theory of Animation in Material Media. Konsthistorisk Tidsskrift 86: 251-70. [CrossRef]

Lund, Julie. 2017. Connectedness with things. Animated objects of Viking Age Scandinavia and early medieval Europe. Archaeological Dialogues 24: 89-108. [CrossRef]

Hall, Mark A. 2011. The Cult of Saints in Medieval Perth: Everyday Ritual and the Materiality of Belief. Journal of Material Culture 16: 80-104. [CrossRef]

Marks, Richard. 2004. Image and Devotion in Late Medieval England. London: Sutton.

Martinelli, Stefano. 2016. L'immagine del Volto Santo di Lucca. Il successo europeo di un'iconografia medievale [The Image of the Volto Santo from Lucca. The European Success of a Medieval Iconography]. Pisa: Edizioni ETS.

Matyjaszkiewicz, Ika. 2018. Distance and Embrace: Spatial Conditions of Access to the Volto Santo of Lucca. In Place and Space in the Medieval World. Edited by Meg Boulton, Jane Hawkes and Heidi Stoner. London: Routledge (e-book).

Mauss, Marcel. 1923. Essai sur le don [Essay on the Gift]. In L'Année sociologique [Yearbook of Sociology]. Edited by Émile Durkheim. Paris: Alcan, pp. 30-186.

Ó Carragáin, Éamonn. 2005. Ritual and the Rood: Liturgical Images and the Old English Poems of the Dream of the Rood Tradition. London: The British Library and Toronto: University of Toronto Press.

Van Os, Henk, Eugène Honoré, Hans Niewdorp, and Bernard Ridderbos. 1994. The Art of Devotion in the Late Middle Ages in Europe, 1300-1500. Princeton: Princeton University Press.

Palsson, Vidar. 2010. Power and Political Communication. Feasting and Gift Giving in Medieval Iceland. Ph.D. dissertation, University of California, Berkeley, CA, USA.

Pongratz-Leisten, Beate, and Karen Sonik. 2015. The Materiality of Divine Agency. Boston and Berlin: De Gruyter.

Ringbom, Sixten. 1984. Icon to Narrative: The Rise of the Dramatic Close-Up in Fifteenth-Century Devotional Painting. Doornspijk: Davaco.

Rosler, Martha, Caroline Walker Bynum, Natasha Eaton, Michael Ann Holly, Amelia Jones, Michael Kelly, Robin Kelsey, Alisa LaGamma, Monika Wagner, Oliver Watson, and et al. 2013. Notes from the Field: Materiality. The Art Bulletin 95: 10-37. [CrossRef]

Rubin, Miri. 1991. Corpus Christi: The Eucharist in Late Medieval Culture. Cambridge: Cambridge University Press.

Schmitt, Jean Claude. 1995. Cendrillon crucifiée. À propos du Volto santo de Lucqus [The Crucified Cinderella. Some Thoughts on the Volto Santo from Lucca]. In Miracles, Prodiges et Merveilles au Moyen Âge, Actes du XXVe Congrès de la S.H.M.E.S, Orléans, Juin 1994 [Miracles, Prodigies and Wonders in the Middle Ages. Proceedings from the 25th Congress of the S.H.M.E.S. in Orleans, June 1994]. Paris: Publications de la Sorbonne, pp. 241-69.

Skinnebach, Laura Katrine, and Henning Laugerud. 2007. Instruments of Devotion: The Practices and Objects of Religious Piety from the Late Middle Ages to the 20th Century. Aarhus: Aarhus Universitetsforlag.

Smail, Daniel Lord. 2016. Law and the Uncertainty of Value in Late Medieval Marseille and Lucca. In The Dark Side of Knowledge: Histories of Ignorance, 1400 to 1800. Edited by Cornel Zwierlein. Leiden: Brill, pp. 51-69.

Smith, Mary Francis, Robin Fleming, and Patricia Halpin. 2001. Court Piety in Anglo-Saxon England. The Catholic Historical Review 87: 569-602. [CrossRef]

Staecker, Jörn. 1999. Rex Regum et Dominus Dominorum: Die wikingerzeitlichen Kreutz- und Kruzifixanhänger als Ausdruck der Mission in Altdänemark und Schweden [Rex Regnun et Dominus Dominorum: The Cross- and Crucifix Pendants of the Vikings as Missionary Symbols in Old Denmark and Sweden]. Stockholm: Almqvist and Wiksell.

Staecker, Jörn. 2006. The Cross Goes North: Christian Symbols and Scandinavian Women. In The Cross Goes North: Processes of Conversion in Northern Europe, AD 300-1300. Edited by Martin Carver. Woodbridge: Boydell Press, pp. 463-82.

Stang, Margrethe C. 2015. Bildedonasjoner og donatorbilder. Lekfolks gaver til kirken som visuell kultur [Image Donations and Donator Images. Lay People's Gifts to the Church as Visual Culture]. Collegium Medievale 28: 145-62.

Trexler, Richard C. 1991. Habiller et déshabiller les images, esquisse d'une analyse [Dressing and Undressing Images, an Analytical Sketch]. In L'image et la Production du Sacré [The Image and the Production of the Sacred]. Edited by François Dunand, Jean-Michel Spieser and Jean Wirth. Pairs: Méridiens Klincksieck, pp. 195-231.

Tripps, Johannes. 2000. Das Handelnde Bildwerk in der Gotik [The Acting Image in the Gothic Period]. Berlin: Gebrüder Mann Verlag. 
Il Volto Santo. 2003. La Santa Croce di Lucca: il Volto Santo: Storia, Tradizioni, Immagini. Atti del Convegno, Villa Bottini 1-3 Marzo 2001 [The Holy Cross from Lucca: the Volto Santo. History, Traditions, Images. Proceedings from Villa Bottini 1-3 March 2001]. Edited by Marzia Zingoni. Empoli: Editori dell'Acero.

Weiner, Annette. 1992. Inalienable Possessions: The Paradox of Keeping-While-Giving. Berkeley: University of California Press.

(c)

(C) 2019 by the author. Licensee MDPI, Basel, Switzerland. This article is an open access article distributed under the terms and conditions of the Creative Commons Attribution (CC BY) license (http://creativecommons.org/licenses/by/4.0/). 